\title{
Filipe Melanchthon (1497-1560): vida, obra e figura do outro reformador de Wittenberg
}

Orientador: Luís Corrêa Lima

Mestrando: Paulo Samuel Albrecht

Área de Concentração: Teologia Sistemático-Pastoral

Linha de Pesquisa: Religião e Modernidade

Este trabalho procura resgatar a importante contribuição de Filipe Melanchthon para o movimento reformatório europeu do século XVI, trazendo uma biografia de sua vida e carreira, abordando aspectos centrais de sua teologia e a como eles também ajudaram a moldar o discurso reformatório a partir de Wittenberg para toda a Europa. De maneira especial, enfatiza-se a historiografia de Melanchthon desde a época da Reforma, procurando desfazer-se rótulos e juízos de valor infundados sobre a sua pessoa, especialmente no que se refere a ser considerado um auxiliar sem grandes contribuições originais ou, pior ainda, um traidor da causa luterana. Busca-se, ainda, apontar para os novos rumos atuais da pesquisa teológica sobre a sua pessoa na Europa e nos Estados Unidos, com o intuito de estimular a pesquisa sobre este assunto também no Brasil. Ao final, verifica-se que a Melanchthon foi destinada uma posição obscura na pesquisa histórica do movimento reformatório europeu, o que não condiz com a grandeza e a importância de suas contribuições para aquela época e também daquilo que pode servir de estímulo ao refletir teológico atual.

Palavras-chave: Filipe Melanchthon (1497-1560); reforma protestante; século XVI. 